\title{
Balanced rearrangements of the autosomes: results of a longitudinal study of a newborn survey population
}

\author{
I TIERNEY, D AXWORTHY, L SMITH, AND S G RATCLIFFE \\ From the MRC Clinical and Population Cytogenetics Unit, Western General Hospital, \\ Edinburgh EH4 $2 \mathrm{XU}$.
}

SUMMARY Thirty-six infants were identified by cytogenetic screening at birth as having balanced rearrangements of their autosomes, and 30 of them took part in a longitudinal study of their development, together with four of their affected sibs. With the exception of one child with a de novo reciprocal translocation who died, all children attended normal schools. Congenital malformations and short stature were present in only one child who had a de novo reciprocal translocation. The IQ scores of the 10 children with de novo translocations were significantly lower than those of the 20 children with familial translocations, but there were children in the de novo group of above average intelligence. Children with familial reciprocal translocations had significantly higher IQ scores than both the Robertsonian translocations and the controls, but the numbers in each category were small and a variety of different chromosomes were involved.

The effect of an abnormal karyotype on human brain development and subsequent cognitive ability is critical for antenatal counselling and for accurate prognosis in the liveborn. However, the available information on the effect of balanced rearrangements of the autosomes on cognitive and physical development is heavily biased by selective ascertainment in abnormal persons or environments.

In 1972 , Breg et al $^{1}$ suggested that there might be an increased incidence of balanced reciprocal translocations among the seriously mentally retarded population, having identified four cases among 1000 such subjects. In 1974, Jacobs ${ }^{2}$ described results from Edinburgh of chromosome analysis on 33533 persons, 12 of whom were found to have de novo translocations. When the source of ascertainment was examined it was found that a significantly greater proportion came from the mentally retarded institutions that had been surveyed than from the 12295 newborns examined. These results suggested that the possession of a de novo structural euploid rearrangement of the autosomes was, in some cases, associated with severe mental retardation, and Jacobs commented that the newborn survey followup data would be required to give a precise prognosis.

Numerous cytogenetic surveys of mentally

Received for publication 22 August 1983.

Accepted for publication 26 August 1983. retarded populations have been undertaken, mainly at institutions. The study of Speed $e t a l^{3}$ was unique in that it aimed at surveying a complete population of mentally subnormal patients at home or in hospital. Despite examining 2770 persons, none was found with a balanced autosomal rearrangement, although the incidence of other types of chromosome abnormalities was similar to that found in other surveys. The authors comment that there may have been underascertainment of high grade defectives in rural areas, and in fact the number certified was considerably less than the 10000 expected in the population of 500000 at a $2 \%$ mental subnormality rate; this may be partly accounted for by early deaths.

In a survey of a Child Psychiatric and Mental Retardation Clinic, Funderburk et al $^{4}$ found seven 'balanced' autosomal rearrangements among 455 mentally retarded children compared with four among 1679 psychiatric patients. Reciprocal translocations and pericentric inversions only were identified. Review of published reports covering chromosome analysis in 5048 mentally retarded persons confirmed an excess of de novo translocations, specifically of the non-Robertsonian type. This finding was confirmed by Jacobs et $a l^{5}$ in a survey in Hawaii and by Fryns and van der Berghe. ${ }^{6}$

As regards the association of congenital malformations with balanced autosomal rearrangements, the 
original reports of the newborn cytogenetic surveys did not reveal any increased incidence, despite the fact that there had been numerous reports of cases of de novo balanced translocations identified on account of multiple congenital malformations. ${ }^{7}$

The effect of balanced rearrangements, familial or de novo, on development will be determined definitively when there is sufficient information on large numbers of cases who have been identified by newborn screening and compared with adequate controls from the same population. In their paper dealing mainly with the inheritance and cytogenetics of translocations, Evans et $a l^{8}$ also presented follow-up information on 24 infants with balanced autosomal rearrangements from the newborn survey of 14069 infants in Winnipeg. It was not possible to state with certainty whether any of the children had de novo rearrangements owing to incomplete family studies. Only minor physical differences (upward slanting palpebral fissures and dermatoglyphic patterns) were noted on examination. Six of the 24 children were old enough for psychometric assessment and their mean IQ score was not significantly different from that of a small control group.

Nielsen and Krag-Olsen ${ }^{9}$ reported follow-up of the 32 children with autosomal translocations found among 11148 consecutive newborn infants in Denmark based on a parent or teacher report or both. All five de novo translocations were described as having normal mental development, while three abnormalities were reported among the 27 familial translocations: one case each of psychiatric referral, mental retardation, and early death. While generally reassuring, the report lacks any psychometric assessment of probands and controls.

In this communication we present the results from the Edinburgh newborn survey of a longitudinal study on 30 of the 36 children identified as having balanced autosomal rearrangements, and on four of their affected sibs, comparing their results with a large control group from the same population.

\section{Material and methods}

The methodology of the original cytogenetic surveys has been described in detail elsewhere. ${ }^{10} 11$ Of 15673 infants who had full chromosome analysis shortly after birth, 36 were found to have balanced autosomal rearrangements. Children with inversion of chromosome 9 were considered to have a normal variant. Parents were informed of their child's chromosome constitution and in the majority of cases parental karyotypes were also obtained. With parental permission the children were enrolled in the Edinburgh Longitudinal Study of Growth and Development, along with 67 children with sex chromosome abnormalities and the controls. Details $\Phi$ of the assessment protocol have been published..$^{12} \mathbb{\Phi}$ The controls used in this study were children with $\Rightarrow$

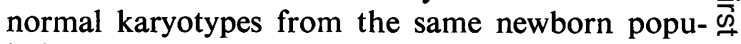
lation. The social class distribution in this group was similar to that of the probands, social class being $\frac{\bar{\sigma}}{\bar{G}}$ categorised by the father's occupation at the time of $\frac{\bar{\omega}}{\bar{\sigma}}$ the child's birth (social class 1, professional, to social $\stackrel{\Phi}{\stackrel{\Phi}{\varrho}}$ class 5 , unskilled).

Cognitive ability was assessed by a psychologist

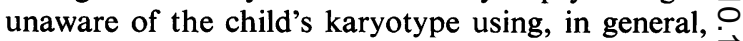
the McCarthy Scale of Children's Abilities (MSCA) ${ }^{13} \overrightarrow{\vec{\omega}}$ for children under the age of 7 years (range 4.4 to $\stackrel{\omega}{\omega}$ 5.9 years) and the Wechsler Intelligence Scale for $\overline{\overline{3}}$ Children (WISC) ${ }^{14}$ for those over that age (range $6 \cdot 1$ to $7 \cdot 7$ years).

$\mathrm{Z}$ scores of the IQ were calculated from the formula $Z=I Q$ score for proband-mean IQ score for controls Standard deviation of the mean IQ score for controls. Group comparisons were made using Student's $t \stackrel{\text { T }}{O}$ test for samples of unequal variance, except when the nature of the data dictated the use of Fisher's exact test. A level of significance where $\mathrm{p}<0.05 \overrightarrow{-}$ (two tailed) was used throughout unless otherwise $\infty$ stated.

\section{Results}

CONTROLS

In 128 children ( 66 boys and 62 girls) under the age of 7 the mean MSCA score was 110.2 SD 14.0. For the 92 children ( 48 boys and 44 girls) over the age of 7 a higher score of 118.3 SD 13.7 was obtained using the WISC. (The explanation for this apparent disparity lies in the fact that the WISC was standardised in 1949, and the population mean score is influenced by secular changes. Flynn ${ }^{15}$ has calculated that a rise of 0.3 IQ points occurs annually in the mean population score, requiring restandardisation of IQ tests at intervals. Since this study was started the revised form WISC-R has been introduced to overcome this problem but results from the WISC cannot be transposed directly. To facilitate comparisons, test results have been converted into $\mathrm{Z}$ scores.)

DE NOVO TRANSLOCATIONS

The results of the IQ tests and details of the karyo- N type are given in table 1 and show a wide range from $\sigma$ less than 50 up to 136 . It should be noted that all surviving children attended normal schools, although $\underset{\mathbb{D}}{\stackrel{D}{(}}$ two required remedial teaching and one speech $\stackrel{\mathcal{D}}{\rightarrow}$ therapy. Clinical data are presented in table 2, 0 illustrating that phenotypic abnormalities were 0 present only in case 8 . The mean age of the mothers

\section{,}


TABLE 1 De novo translocations: intelligence quotients and karyotypes.

\begin{tabular}{lllll}
\hline $\begin{array}{l}\text { ID } \\
N o\end{array}$ & $\begin{array}{l}\text { Social } \\
\text { class }\end{array}$ & $I Q$ & $\begin{array}{l}I Q \\
Z \text { score }\end{array}$ & Karyotype \\
\hline 1 & 1 & 136 & $+1 \cdot 84$ & $46, \mathrm{XX}, \mathrm{t}(4 ; 9)(\mathrm{p} 12 ; \mathrm{q} 32)$ \\
2 & 2 & 122 & $+0 \cdot 84$ & $46, \mathrm{XX}, \mathrm{t}(11 ; 15)(\mathrm{p} 15 ; \mathrm{q} 15)$ \\
3 & 3 & 122 & +0.84 & $45, \mathrm{XX}, \mathrm{t}(13 \mathrm{q} ; 14 \mathrm{q})$ \\
4 & 2 & 109 & -0.68 & $45, \mathrm{XX}, \mathrm{t}(13 ; 14)(\mathrm{p} 11 ; \mathrm{q} 11)$ \\
5 & 2 & 101 & $-1 \cdot 26$ & $45, \mathrm{XX}, \mathrm{t}(14 \mathrm{q} ; 21 \mathrm{q})$ \\
6 & 4 & 101 & $-1 \cdot 26$ & $46, \mathrm{XX}, \mathrm{t}(1 ; 15)(\mathrm{q} 2 ; \mathrm{q} 15$ or 21 or 22$)$ \\
7 & 1 & $96^{*}$ & -0.27 & $46, \mathrm{XY}, \mathrm{t}(6 ; 9)(\mathrm{q} 25 ; \mathrm{p} 13)$ \\
8 & 2 & 95 & $-1 \cdot 70$ & $46, \mathrm{XY}, \mathrm{t}(6 ; 7)(\mathrm{q} 23 ; \mathrm{q} 22)$ \\
9 & 3 & 84 & $-2 \cdot 50$ & $46, \mathrm{XX}, \mathrm{t}(2 ; 10)(\mathrm{q} 11 ; \mathrm{q} 22)$ \\
10 & 3 & $<50$ & $-3 \cdot 00$ & $46, \mathrm{XY}, \mathrm{t}(5 ; 11)(\mathrm{p} 11 ; \mathrm{p} 15)$ \\
\hline
\end{tabular}

*WISC-R : see acknowledgements.

( 28.8 years) and fathers ( 31.9 years) of these children was slightly, but not significantly, greater than that of the control mothers (27.4 years) and fathers (29.2 years).

The mean $\mathrm{Z}$ score for IQ of this group was $-0 \cdot 72+1.47$. While one of the children would almost certainly have required institutional care had he survived, there were three children in this group with above average cognitive ability, and one child was in the superior range. As a group, their mean IQ score was not significantly lower than that of the control group, but it was significantly lower than that of all the familial rearrangements $(p<0.01$ one tailed) and of the combined familial reciprocal and Robertsonian translocations $(p<0.025$ one tailed). In view of the chromosomal heterogeneity of this small group, it is more meaningful to consider their results individually rather than to amalgamate their widely differing scores.

\section{FAMILIAL REARRANGEMENTS \\ Robertsonian translocations}

The IQ scores and karyotypes for the seven children in this group, together with results for two of their sibs, are given in table 3 and the clinical information in table 4 . The mean $\mathrm{Z}$ score for cognitive ability in this group was $-0 \cdot 10 \div 0.94$ and was not significantly different from that of the controls. Phenotypically, three children had minor malformations but all were healthy and attended normal schools.

\section{Reciprocal translocations}

The IQ scores and karyotypes for the seven children

TABLE 3 Familial Robertsonian translocations: intelligence quotients and karyotypes.

\begin{tabular}{llllll}
\hline $\begin{array}{l}\text { ID } \\
\text { No }\end{array}$ & $\begin{array}{l}\text { Social } \\
\text { class }\end{array}$ & $I Q$ & $\begin{array}{l}I Q \\
Z \text { score }\end{array}$ & Karyotype & Origin \\
\hline 11 & 2 & 138 & -1.44 & $45, \mathrm{XY}, \mathrm{t}(14 \mathrm{q} ; 22 \mathrm{q})$ & Paternal \\
12 & 1 & 132 & -1.00 & $45, \mathrm{XX}, \mathrm{t}(13 \mathrm{q} ; 22 \mathrm{q})$ & Paternal \\
13 & 3 & 117 & -0.09 & $45, \mathrm{XX}, \mathrm{t}(13 \mathrm{q} ; 14 \mathrm{q})$ & Paternal \\
14 & 3 & 109 & -0.09 & $45, \mathrm{XY}, \mathrm{t}(13 \mathrm{q} ; 14 \mathrm{q})$ & Maternal \\
15 & 3 & 109 & -0.68 & $45, \mathrm{XX}, \mathrm{t}(13 \mathrm{q} ; 14 \mathrm{q})$ & Paternal \\
16 & 3 & 105 & -0.97 & $45, \mathrm{XY}, \mathrm{t}(14 \mathrm{q} ; 22 \mathrm{q})$ & Paternal \\
17 & 2 & 100 & -1.34 & $45, \mathrm{XY}, \mathrm{t}(13 \mathrm{q} ; 14 \mathrm{q})$ & Paternal \\
$18 *$ & 1 & 127 & & $45, \mathrm{XY}, \mathrm{t}(13 \mathrm{q} ; 22 \mathrm{q})$ & Paternal \\
$19 \dagger$ & 3 & 125 & & $45, \mathrm{XY}, \mathrm{t}(13 \mathrm{q} ; 14 \mathrm{q})$ & Paternal \\
\hline
\end{tabular}

*Sib of case 12 .

+ Sib of case 15 .

TABLE 2 Clinical information on children with de novo translocations.

\begin{tabular}{|c|c|c|c|c|c|c|c|}
\hline \multirow[t]{2}{*}{$I D N o$} & \multicolumn{2}{|c|}{ Parental age } & \multirow{2}{*}{$\begin{array}{l}\text { Pregnancy and } \\
\text { delivery }\end{array}$} & \multirow{2}{*}{$\begin{array}{l}\text { Birth weight } \\
(\mathrm{kg})\end{array}$} & \multirow{2}{*}{$\begin{array}{l}\text { Congenital } \\
\text { malformations }\end{array}$} & \multirow{2}{*}{$\begin{array}{l}\text { Height } \\
\text { centile }\end{array}$} & \multirow[t]{2}{*}{ Progress } \\
\hline & Mother & Father & & & & & \\
\hline 1 & 26 & 29 & $\begin{array}{l}\text { PET } \\
\text { Nornal delivery }\end{array}$ & $3 \cdot 02$ & None & 75 & $\begin{array}{l}\text { Infantile eczema (familial), } \\
\text { otherwise healthy }\end{array}$ \\
\hline 2 & 24 & 32 & Normal & $3 \cdot 40$ & None & 50 & Healthy child \\
\hline 3 & 27 & 36 & $\begin{array}{l}\text { Normal pregnancy } \\
\text { Breech delivery }\end{array}$ & $3 \cdot 21$ & None & & Healthy child \\
\hline 4 & 26 & 27 & Normal & $2 \cdot 69$ & None & 25 & Healthy child \\
\hline 5 & 34 & 42 & Normal & $3 \cdot 50$ & $\begin{array}{l}\text { Dislocatable } \mathbf{R} \\
\text { hip at birth }\end{array}$ & 3 & $\begin{array}{l}\text { Myoclonic epilepsy aged } 3 \text { weeks. } \\
\text { Normal EEG. Complete recovery } \\
\text { in } 3 \text { weeks. Normal child }\end{array}$ \\
\hline 6 & 24 & 27 & $\begin{array}{l}\text { Normal pregnancy } \\
\text { Caesarian section }\end{array}$ & $3 \cdot 06$ & $\begin{array}{l}\text { Partially dislocatable } \\
\text { hips at birth }\end{array}$ & 50 & Healthy child \\
\hline 7 & 27 & 30 & Normal & $3 \cdot 17$ & None & 25 & Healthy child \\
\hline 8 & 30 & 33 & $\begin{array}{l}\text { PET } \\
\text { Normal delivery } \\
\quad \text { (at } 37 \text { weeks) }\end{array}$ & $1 \cdot 94$ & $\begin{array}{l}\text { Abnornal facies, } \\
\text { hypospadias, and ch }\end{array}$ & $\begin{array}{l}-3 \cdot 0 \\
\text { ee SD }\end{array}$ & $\begin{array}{l}\text { Marked delay of speech development. } \\
\text { Normal school, remedial teaching. } \\
\text { Speech therapy }\end{array}$ \\
\hline 9 & 23 & 25 & Normal & $3 \cdot 88$ & None & 50 & $\begin{array}{l}\text { Healthy child. Remedial teaching at } \\
\text { normal school }\end{array}$ \\
\hline 10 & 41 & 40 & $\begin{array}{l}\text { Antepartum } \\
\text { haemorrhage } \\
\text { Normal delivery }\end{array}$ & $3 \cdot 62$ & None & & $\begin{array}{l}\text { Age } 9 \text { weeks, develorment delayed, } \\
\text { onset of screaming fits, then } \\
\text { myoclonic epilepsy. EEC abnormal, } \\
\text { spike and wave complexes. } \\
\text { Progressive deterioration with } \\
\text { grand mal epilepsy until death at age } \\
3 \text { years } 11 \text { months. No necropsy }\end{array}$ \\
\hline
\end{tabular}

PET = pre-eclamptic toxaemia. 
TABLE 4 Familial Robertsonian translocations: clinical information.

\begin{tabular}{|c|c|c|c|c|c|}
\hline$I D N o$ & $\begin{array}{l}\text { Pregnancy and } \\
\text { delivery }\end{array}$ & $\begin{array}{l}\text { Birth } \\
\text { ueight }(k g)\end{array}$ & $\begin{array}{l}\text { Congenital } \\
\text { malfermations }\end{array}$ & $\begin{array}{l}\text { Height } \\
\text { centile }\end{array}$ & Progress \\
\hline 11 & $\begin{array}{l}\text { Mild PET } \\
\text { Forceps delivery }\end{array}$ & $3 \cdot 36$ & None & 75 & Healthy child \\
\hline 12 & PET & $3 \cdot 28$ & None & 3 & Healthy child \\
\hline 13 & Normal & $3 \cdot 35$ & None & 90 & Healthy child \\
\hline 14 & Normal & $3 \cdot 60$ & Hypospadias & 10 & Healthy child \\
\hline 15 & $\begin{array}{l}\text { Normal pregnancy } \\
\text { Forceps delivery }\end{array}$ & $4 \cdot 36$ & None & 75 & Healthy child \\
\hline 16 & PET & $3 \cdot 57$ & None & 75 & Healthy child \\
\hline 17 & Normal & $3 \cdot 02$ & $\begin{array}{l}\text { Syndactyly of } 2 \text { nd and } 3 \text { rd } \\
\text { toes on both feet (familial) }\end{array}$ & 25 & Healthy child \\
\hline 18 & Normal & $3 \cdot 68$ & Minor degree of hypospadias & 10 & $\begin{array}{l}\text { Healthy child } \\
\text { Daytime wetting up to } 8 \text { years }\end{array}$ \\
\hline 19 & Normal & $3 \cdot 78$ & None & 25 & $\begin{array}{l}\text { Surviving twin, } \\
\text { other was fetus papyraceous }\end{array}$ \\
\hline
\end{tabular}

SVD $=$ spontaneous vertex delivery.

TABLE 5 Familial reciprocal translocations: intelligence quotients and karyotypes.

\begin{tabular}{|c|c|c|c|c|c|}
\hline $\begin{array}{l}\text { ID } \\
\text { No }\end{array}$ & $\begin{array}{l}\text { Social } \\
\text { class }\end{array}$ & $I Q$ & $\begin{array}{l}I Q \\
Z \text { score }\end{array}$ & Karyotype & Origin \\
\hline 20 & 4 & 131 & +0.93 & $46, X Y, t(1 ; 14)(q 42 ; q 23)$ & Maternal \\
\hline 21 & 3 & 131 & +0.93 & $\begin{array}{l}46, \mathrm{XX}, \mathrm{t}(3 ; 13)(\mathrm{q} 12 \\
\quad \text { or } 13 ; \mathrm{q} 31)\end{array}$ & Maternal \\
\hline 22 & 5 & 130 & $1 \cdot 41$ & $46, X \times, t(11 q-; 13 q+)$ & Maternal \\
\hline 23 & 5 & 127 & 0.64 & $46, X Y, t(11 q-; 13 q+)$ & Maternal \\
\hline 24 & 3 & 125 & 0.49 & $46, X X, t(3 ; 7)(\mathrm{p} 14 ; \mathrm{p} 22)$ & Maternal \\
\hline 25 & 3 & 124 & +0.99 & $46, X X, t(7 ; 11)(\mathrm{p} 22 ; \mathrm{q} 23)$ & Maternal \\
\hline 26 & 3 & 117 & -0.09 & $46, X Y, t(11 ; 19)(q 14 ; q 13)$ & Maternal \\
\hline
\end{tabular}

in this group are shown in table 5 and the clinical information in table 6 . Here the mean $\mathrm{Z}$ score for cognitive ability of $0.76 \pm 0.44$ was significantly higher than that of the controls $(p<0.05)$ and of the familial Robertsonian translocations $(p<0 \cdot 05)$. Only one child had a score marginally below the mean for the control group. The mean social class of this group at $3.43 \pm 0.73$ was significantly lower than that of the Robertsonian group at $2.43 \pm 0.73$. While the numbers are small this further accentuates the higher ability of the reciprocal translocation group. The health and growth of these children was unremarkable and there were no congenital malformations.

\section{$Y$; autosomal translocations and inversions}

The IQ scores, karyotypes, and clinical information for these six children, together with that of two affected sibs, appear in tables 7 and 8 . As there were $\overrightarrow{0}$

TABLE $7 \quad Y ; 15$ translocations and inversions: intelligence quotients and karyotypes.

\begin{tabular}{llllll}
\hline $\begin{array}{l}I D \\
N o\end{array}$ & $\begin{array}{l}\text { Social } \\
\text { class }\end{array}$ & $I Q$ & $\begin{array}{l}I Q \\
Z \text { score }\end{array}$ & Karyotype & Origin \\
\hline 27 & 3 & 121 & +0.20 & $46, \mathrm{XY}, \mathrm{t}(\mathrm{Y} ; 15)(\mathrm{q} 12 ; \mathrm{p} 11)$ & Paternal \\
28 & 3 & 110 & 0.61 & $46, \mathrm{XY}, \mathrm{t}(\mathrm{Y} ; 15)(\mathrm{q} 12 ; \mathrm{p} 11)$ & Paternal \\
29 & 3 & $105^{*}$ & 0.37 & $46, \mathrm{XY}, \mathrm{t}(\mathrm{Y} ; 15)(\mathrm{q} 12 ; \mathrm{p} 11)$ & Paternal \\
30 & 1 & 133 & +1.07 & $46, \mathrm{XX}, \operatorname{inv}(1)(\mathrm{p} 32 ; \mathrm{q} 42)$ & Maternal \\
31 & 2 & 125 & +0.49 & $46, \mathrm{XX}, \operatorname{inv}(6)(\mathrm{p} 21 ; \mathrm{q} 21)$ & Paternal \\
32 & 3 & 121 & +0.77 & $46, \mathrm{XX}, \operatorname{inv}(2)(\mathrm{p} 11 ; \mathrm{q} 13)$ & Paternal \\
$33+$ & 2 & 143 & & $46, \mathrm{XY}, \operatorname{inv}(6)(\mathrm{p} 21 ; \mathrm{q} 21)$ & Paternal \\
$34 \ddagger$ & 3 & 117 & & $46, \mathrm{XX}, \operatorname{inv}(2)(\mathrm{p} 11 ; \mathrm{q} 13)$ & Paternal \\
\hline
\end{tabular}

*WISC-R: see acknowledgements.

tSib of case 31 .

$\ddagger$ Sib of case 32 .

TABLE 6 Familial reciprocal translocations: clinical information.

\begin{tabular}{|c|c|c|c|c|c|}
\hline ID No & $\begin{array}{l}\text { Pregnancy and } \\
\text { delivery }\end{array}$ & $\begin{array}{l}\text { Birth } \\
\text { weight }(k g)\end{array}$ & Congenital malformations & $\begin{array}{l}\text { Height } \\
\text { centile }\end{array}$ & Progress \\
\hline 20 & Normal & 3.09 & None & 90 & Healthy child \\
\hline 21 & Normal & $3 \cdot 06$ & None & 10 & Healthy child \\
\hline 22 & $\begin{array}{l}\text { Maternal UTI } \\
\text { Caesarian }\end{array}$ & $3 \cdot 71$ & None & 75 & Healthy child \\
\hline 23 & $\begin{array}{l}\text { Mild PET } \\
\text { Caesarian }\end{array}$ & $3 \cdot 30$ & None & 25 & Healthy child \\
\hline 24 & $\begin{array}{l}\text { PET } \\
\text { Normal delivery }\end{array}$ & $4 \cdot 70$ & None & 50 & Healthy child \\
\hline 25 & $\begin{array}{l}\text { Maternal UTI } \\
\text { Normal delivery }\end{array}$ & $2 \cdot 98$ & None & 90 & Healthy child \\
\hline 26 & $\begin{array}{l}\text { Normal pregnancy } \\
\text { Forceps delivery }\end{array}$ & $3 \cdot 78$ & None & 50 & Fractured clavicle at birth \\
\hline
\end{tabular}


TABLE $8 \quad Y ; 15$ translocations and inversions: clinical information.

\begin{tabular}{|c|c|c|c|c|c|}
\hline$I D N o$ & $\begin{array}{l}\text { Pregnancy and } \\
\text { delivery }\end{array}$ & $\begin{array}{l}\text { Birth } \\
\text { weight }(\mathrm{kg})\end{array}$ & Congenitaí malformations & $\begin{array}{l}\text { Height } \\
\text { centile }\end{array}$ & Progress \\
\hline 27 & Normal & $3 \cdot 49$ & None & 25 & $\begin{array}{l}\text { Maternal atypical tuberculosis } \\
\text { treated during pregnancy. Child } \\
\text { treated postnatally. Behaviour } \\
\text { problems after maternal desertion }\end{array}$ \\
\hline 28 & Normal & $3 \cdot 04$ & None & 50 & Healthy child \\
\hline 29 & $\begin{array}{l}\text { Threatened abortion } \\
\text { at } 25 \text { weeks }\end{array}$ & $3 \cdot 62$ & None & 90 & $\begin{array}{l}\text { Behaviour problems and learning } \\
\text { difficulties. Poor visual-motor } \\
\text { abilities. Psychiatric referral. Father } \\
(Y ; 15) \text { had same problems in childhood }\end{array}$ \\
\hline 30 & Normal & $3 \cdot 83$ & None & 97 & Healthy child \\
\hline 31 & Normal & $3 \cdot 63$ & Haemangioma on left foot & 75 & Eczema and asthma (familial) \\
\hline 32 & Normal & $3 \cdot 27$ & None & 90 & Healthy child \\
\hline 33 & $\begin{array}{l}\text { Normal pregnancy } \\
\text { Forceps delivery }\end{array}$ & $4 \cdot 15$ & None & 75 & $\begin{array}{l}\text { Eczema and asthma (familial) } \\
\text { Neonatal jaundice requiring } \\
\text { phototherapy }\end{array}$ \\
\hline 34 & Normal & $3 \cdot 27$ & None & 75 & Healthy child \\
\hline
\end{tabular}

only three children in each group mean scores have not been calculated.

Behaviour problems were present in two of the $\mathrm{Y}$; autosomal translocations, one probably being of environmental origin (case 27), while those present in case 29 may have had some association with the karyotype as the father was similarly affected.

The combined $\mathrm{Z}$ score for IQ for all 20 children in the group was $0 \cdot 31 \pm 0 \cdot 78$. The children with familial Robertsonian and reciprocal translocations had a mean $\mathrm{Z}$ score for IQ of $0 \cdot 33 \pm 0 \cdot 85$. Neither of these two groups was significantly different from the controls.

Comparison of the seven de novo reciprocal translocations with the seven familial reciprocal translocations does reveal a significant deficit in IQ score for the former group $(\mathrm{p}<0 \cdot 05)$.

\section{MISCELLANEOUS CASES WITH LIMITED INFORMATION}

These cases are described in table 9.

\section{ORIGIN OF THE FAMILIAL TRANSLOCATIONS} When the parental origin of the two main groups of familial translocations was examined, it was found that for the Robertsonian translocations six cases were of paternal origin, one was maternal, and no parental information was available for three children. All seven reciprocal translocations were of maternal origin. In this group two of the assessed children were sibs (cases 22 and 23) reducing the maternal origin to six, but as the origin of one of the translocations in the group of children with limited information was also maternal, there remain seven cases of maternal origin.

Examination of the distribution of parental origin of these two groups of translocations in those ten newborn surveys with reasonably complete data is shown in table 10, and suggests that the observed distributions in the Edinburgh study, while significant in both instances $(p<0.04$ Fisher's exact test), were probably chance findings.

TABLE 10 Incidence and origin of balanced autosomal translocation from newborn survey.

\begin{tabular}{|c|c|c|c|c|c|c|c|c|c|}
\hline \multirow[t]{2}{*}{ Reference } & \multirow[t]{2}{*}{ Number } & \multicolumn{4}{|c|}{ Robertsonian } & \multicolumn{4}{|c|}{ Reciprocal } \\
\hline & & $D N$ & mat & pat & Total & $D N$ & mat & pat & Total \\
\hline 16 & 2081 & 0 & 1 & 0 & 1 & 0 & 0 & 0 & 0 \\
\hline 10 & 11680 & 1 & 0 & 6 & $10^{*}$ & 4 & 6 & 0 & 10 \\
\hline 11 & 3993 & 2 & 1 & 0 & 3 & 2 & 2 & 0 & 4 \\
\hline 17 & 14069 & 0 & 6 & 5 & $13 *$ & 1 & 2 & 6 & $11^{*}$ \\
\hline 18 & 2500 & 0 & 1 & 0 & 1 & 2 & 0 & 0 & 2 \\
\hline 19 & 4500 & 0 & 0 & 0 & 0 & 3 & 1 & 1 & $6 *$ \\
\hline 20 & 5049 & 2 & 5 & 2 & 9 & 2 & 2 & 3 & 7 \\
\hline 21 & 6099 & 0 & 5 & 3 & 8 & 1 & 1 & 5 & 7 \\
\hline 22 & 2626 & 0 & 3 & 2 & 5 & 0 & 0 & 0 & 0 \\
\hline 23 & 930 & 0 & 0 & 0 & 0 & 0 & 1 & 0 & 1 \\
\hline 24 & 1830 & 1 & 0 & 3 & 4 & 0 & 3 & 2 & 5 \\
\hline Totals & 55354 & 6 & 22 & 21 & 54 & 15 & 18 & 17 & 53 \\
\hline
\end{tabular}

*Includes cases of unknown origin.

TABLE 9 Miscellaneous cases (limited information).

\begin{tabular}{lllll}
\hline ID No & Social class & Karyotype & Origin & Progress \\
\hline 35 & 1 & $45, \mathrm{XY}, \mathrm{D}-\mathrm{D}-\mathrm{D}(\mathrm{Dq} ; \mathrm{Dq})+$ & Unknown & Healthy child \\
36 & 3 & $45, \mathrm{XY}, \mathrm{D}-\mathrm{D}-\mathrm{t}(\mathrm{Dq} ; \mathrm{Dq})$ & Unknown & Emigrated, untraced \\
37 & 2 & $45, \mathrm{XY}, \mathrm{tdic}(\mathrm{D} ; \mathrm{D})(\mathrm{pl} ; \mathrm{pl})$ & Unknown & Infantile eczema. Normal school. Healthy child \\
38 & 2 & $46, \mathrm{XY}, \mathrm{t}(11 ; 12)(\mathrm{q} 25 ; \mathrm{q} 13)$ & Maternal & Normal until $2 \cdot 5$ years, no further contact \\
39 & 3 & $46, \mathrm{XX}$, inv(8)(p23;q11) & Maternal & Eczema and asthma. Normal school \\
40 & 3 & $46, \mathrm{XX}$, inv $(10)(\mathrm{p} 13 ; \mathrm{q} 22)$ & Maternal & \\
\hline
\end{tabular}




\section{Discussion}

The principal conclusion that can be drawn from these results is that balanced autosomal rearrangements in the main are not as harmful as previous reports would imply. Adverse effects were restricted to three children in the de novo group. Of the 30 children examined, only one (case 10 ) could be categorised as mentally retarded. In addition, one other child (case 9) achieved an IQ score which was 2.5 SD below the mean for the control group and may therefore have been affected by the chromosome abnormality, although her mother is also of low normal intelligence. She is, however, coping within a normal school with remedial teaching for reading. A third child (case 8) had speech and learning difficulties together with markedly reduced stature. There was evidence of impaired intrauterine growth as well as congenital malformation of the genitalia. However, postnatal growth velocity was normal, and with the aid of intensive speech therapy and remedial teaching he is coping in a normal school. There were, however, three children in the de novo group of above average cognitive ability, one of whom is in the superior range.

The large variance in the results of the de novo group is to be expected in view of the differences in the chromosomes and the breakpoints involved but presents difficulties in genetic counselling of prospective parents when amniocentesis has revealed an affected fetus. The literature would imply that there is an appreciable risk of intellectual deficit, but until there are more extensive results on cases with unbiased assessment it remains difficult to quantify the risk.

The children with familial reciprocal translocations achieved IQ scores which were in the main above those of the controls. Bearing in mind the social class distribution already referred to, this is all the more impressive. In order to examine this finding in greater depth a further study comparing sibs carrying the familial reciprocal translocation with those having a normal karyotype is being undertaken.

Claims for increased cognitive ability in groups distinguishable on biological rather than socioeconomic variables have been made previously. It has been suggested that persons with the adrenogenital syndrome ${ }^{25}$ or retinoblastoma ${ }^{26}$ may have increased cognitive ability. These claims are open to criticism of the controls used in the studies. Whereas the numbers involved in this study were small and a chance finding cannot be excluded, the appearance of translocations in evolutionary progress ${ }^{27}$ would not conflict with the suggestion that those reciprocal translocations that survive and are reproduced may

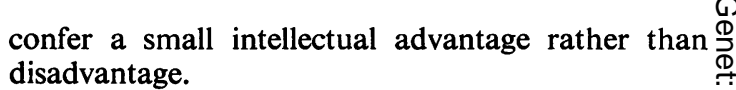

We wish to acknowledge the contribution of $\stackrel{\overrightarrow{\bar{s}}}{\stackrel{9}{9}}$ Dr Patricia Jacobs, Karin Buckton, and the staff of the cytogenetic laboratory for the chromosome $\frac{\bar{\sigma}}{\overline{5}}$ analyses. We would like to thank the following for $\frac{\sigma}{\sigma}$ help or assessment in particular cases: Drs John $\unrhd$ McNamara and F N Fox (Perth, Australia), \& Dr Maria Kwoka, Richard and S Williams, and the $\vec{\circ}$ staff of the Registry. Our further thanks to $\mathrm{Dr}:$ William Yule, Institute of Psychiatry, London, for $\vec{\omega}$ making available to us British normative data on the WISC-R.

\section{References}

1 Breg W, Miller D, Allerdice P, Miller O. Identification of $\vec{c}$ translocation chromosomes by quinacrine fluorescence. 0 Am J Dis Child 1972;123:561-4.

2 Jacobs P. Correlation between euploid structural chro- mosome rearrangement and mental subnormality in Th humans. Nature 1974;249:165-7.

3 Speed R, Johnston A, Evans H. Chromosome survey of total population of mentally subnormal in North-East Scotland. J Med Genet 1976;13:295-306.

4 Funderburk S, Spence M, Sparkes R. Mental retardation $\vec{\bullet}$ associated with 'balanced' chromosome rearrangemento Am J Hum Genet 1977;29:136-41.

5 Jacobs P, Matsura J, Mayer M, Newlands I. A cytogenet survey of an institution for the mentally retarded. Chromosome abnormalities. Clin Genet 1978;13:37-60.

- Fryns JP, Van der Berghe H. Possible excess of mental handicap and congenital malformations in autosomal reciprocal translocations. Ann Genet (Paris) 1979;22: 125-7.

7 Tharapel A, Summit R, Wilroy R, Martens P. Apparently $\overline{\bar{O}}$ balanced de novo translocations in patients with abnormal 3 phenotypes: report of 6 cases. Clin Genet 1977;11:255-69.

8 Evans J, Canning N, Hunter A, et al. A cytogenetic $\vec{F}$ survey of 14,069 newborn infants. III. An analysis of the significance and cytologic behaviour of Robertsonian and reciprocal translocations. Cytogenet Cell Genet 1978;20: 96-123.

9 Nielsen J, Krag-Olsen B. Follow-up of 32 children with autosomal translocations found among 11,148 consecutively newborn children from 1969 to 1974. Clin Genet $1981 ; 20: 48-54$.

10 Jacobs P, Melville M, Ratcliffe S, Keay A, Syme J. A O cytogenetic survey of 11,680 newborn infants. Ann Hum Genet 1974;37:359-76.

11 Buckton K, O'Riordan M, Ratcliffe S, et al. A G-band study of chromosomes in liveborn infants. Ann Hum Genet N 1980;43:227-39.

12 Ratcliffe SG, Axworthy D, Ginsborg A. The Edinburgh study of growth and development in children with sex chromosome abnormalities. In: Robinson A, Lubs $\mathrm{H}, \mathrm{\omega}$ Bergsma D, eds. Sex chromosome aneuploidy: prospective $\widetilde{C}$ studies in children. Birth Defects: Original Article Series Vol 15, No 1. New York: Liss, 1979.

13 McCarthy D. The McCarthy scales of children's abilities. New York: Psychological Corporation, 1972.

14 Wechsler D. The Wechsler intelligence scale for children. New York: Psychological Corporation, 1949.

15 Flynn J. Lynn, the Japanese, and environmentalism. Bull Br Psychol Soc 1982;35:409-13. 
16 Sergovitch F, Valentine G, Chen A, Kinch R, Smout M. Chromosome aberrations in 2,159 consecutive newborn babies. N Engl J Med 1969;280:851-5.

17 Hamerton J, Canning N, Ray M, Smith J. A cytogenetic survey of 14,069 newborn infants. I. Incidence of chromosome abnormalities. Clin Genet 1975;8:223-43.

18 Bochkov P, Kuleshov N, Chebotarev A, Alekhin V, Midian S. Population cytogenetic investigation of newborns in Moscow. Humangenetik 1974;22:139-52.

19 Lubs H, Ruddle F. Application of quantitative karyotype to chromosome variation in 4,400 consecutive newborn. In: Jacobs PA, Price WH, Law P, eds. Human population cytogenetics. Pfizer Medical Monographs 5. Edinburgh: Edinburgh University Press, 1970.

20 Friedrich U, Nielsen J. Chromosome studies in 5,049 consecutive newborn children. Clin Genet 1973;4:333-43.

21 Nielsen J, Sillesen I. Incidence of chromosome aberration in 11,148 newborn children. Hum Genet 1975;30:1-12.

22 Maeda $T$, Ohno M, Takada M, et al. A cytogenetic survey of consecutive liveborn infants: incidence and type of chromosome abnormality. Jpn J Hum Genet 1978;23: 217-24.

23 Lin C, Gedeon M, Griffith P, et al. Chromosome analysis on 930 consecutive newborn children using quinacrine fluorescent banding technique. Hum Genet 1976;31: 315-28.

24 Hansteen IL, Varslot K, Steen-Johnsen J, Langard S. Cytogenetic screening of a newborn population. Clin Cytogenet 1982;21:309-14.

25 Money J, Lewis V, Ehrhardt A, Drash P. IQ impairment and elevation in endocrine and related genetic disorders. In: Zubin J, Jervis G, eds. Psychopathology of mental development. New York: Grune and Stratton, 1967.

26 Williams M. Superior intelligence of children blinded from retinoblastoma. Arch Dis Child 1968;43:204-10.

27 de Grouchy J, Turleau C, Finaz C, Roubin M. Chromosome and gene evolution of man and primates with a detour through the Felidae. In: Boyce AJ, ed. Chromosome variation in human evolution. London: Taylor and Francis, 1975.

Correspondence and requests for reprints to Dr Shirley G Ratcliffe, MRC Clinical and Population Cytogenetics Unit, Western General Hospital, Crewe Road, Edinburgh EH4 2XU.

\section{Addendum}

We have subsequently appreciated that case 8 among the de novo translocations was identified during an interval when chromosome analysis was not being performed on every baby but only on those with congenital malformations, so there was selection in his identification. Consequently the $\mathrm{Z}$ score for the de novo translocations should be $-0.61(1 \cdot 51)$. The comparison between the de novo and the familial translocations remains significant. 